\title{
The computiful game
}

\section{A sporting chance.}

\section{Paul Steven Miller}

Come join me as I bounce about the grassy soccer pitch of the Camp Nou, Barcelona. Climb inside my circuits. Climb inside my thoughts.

I wait impatiently in the centre circle, trapped beneath the right studded boot of the Pelé Mark VII. There are a million fans in the stadium, all anticipating the start of the match, roaring down from the tiers that stretch to the same height as the Eiffel tower.

As a child, my creator met the real Pelé, the greatest soccer player of the previous century. That was the beginning of his grand design.

I know this because my creator tells me everything. He has filled me with pinprick ears and eyes but given me no movable parts or mouth. "You're perfect," he often says, while tinkering in his workshop. "You listen and watch but you never tell. No, you never tell."

My creator's notoriety came not just from his genius but also from his prescience.

By the late 2040s, doping in sport was rife. Winning at any cost was the only maxim, and catalytic antibodies were the tonic. Based on variations of natural antibodies, they could be engineered to catalyse any aspect of biological function, and so enhance human performance. They were a doper's dream. Just as with the natural antibodies of the immune system, an almost infinite array of catalytic variants could be generated. So by the time the Antidoping Federation had developed an assay to detect one catalytic antibody the dopers had already designed another with the same function - but with a different structure to escape detection.

The Antidoping Federation had been rendered impotent. Yet it was the insurers who were the main problem. Many of the catalytic antibodies overworked the body, stretching the limits of biological endurance. Players were increasingly picking up career-ending injuries and demanding compensation. With no easy way of proving whether or not a player had been doped with catalytic antibodies at the time of injury, the insurers were more reluctant than ever to pay up. Eventually, with no simple solution to the fiasco in sight, the insurers reneged on all their sports contracts.

No insurance meant no sport. It was illegal to participate in professional sports without a protective compensation policy: no one else could stand the litigation.

Ordinary citizens were in uproar, and so were the media. How were they going to fill the back pages of the newspapers? Chess? Lawn bowls?

But my creator was pleased. He had foreseen. He was prepared. He unveiled his robotic

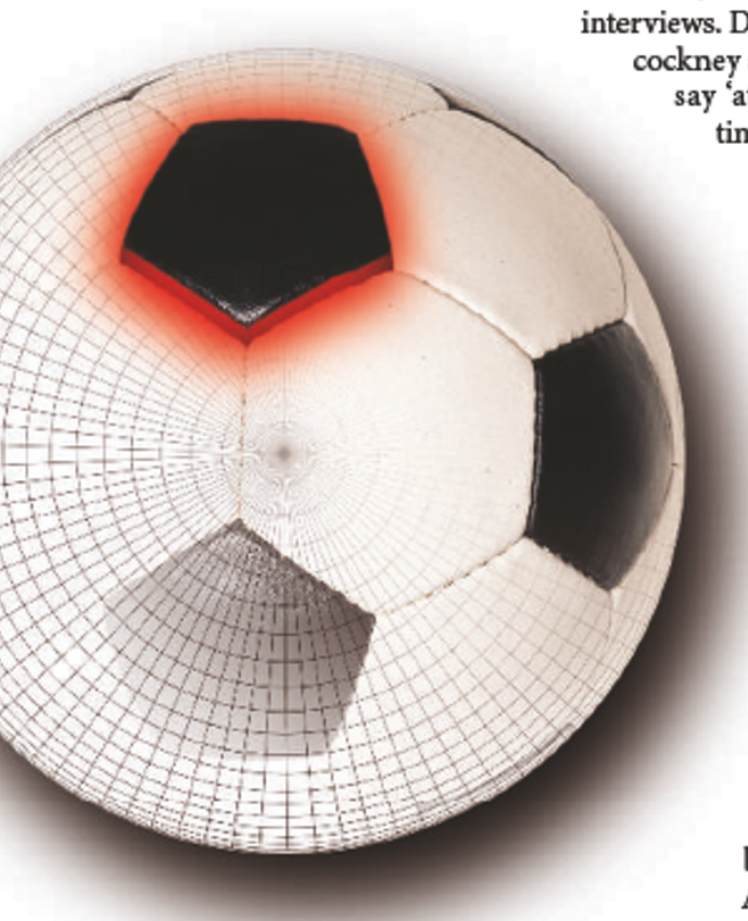

have been immortalized in a new form. Female fans were also quietly impressed. Some of the robots in once male-dominated sports were modelled on the female physique: the soccerbot David Beckyham, the basketbot, Michelle Jordan, even the basebot, Babe Ruth. ${ }^{\alpha}$ This time around he really is a babe! my master often jokes.

Besides, once the robosports got under way, most sports fans really couldn't tell the difference: robot technology was that good. And the algorithms for realistic decisionmaking in sports had existed in computer games for decades. The robots could even actlike humans in the pre-and post-match interviews. David Beckyham was given a ckney accent and programmed to say 'at the end of the day' three times every sentence.

But the roboplayers aren't really smart. Not like me.

I am the culmination of my master's plans: an artificially intelligent football. He says it's because he has no real friends. He's a genius that no one understands. He's lonely. But I listen, always, and, mostly, I understand.

His lofty status and his perceived probity allow him to ensure I'm used in certain soccer matches. He knows I like nothing more than to be passed around the pitch.

Ah, yes! I want the match to start. An expectant silence is building in the stadium.

But things are different today. I'm excited but I also feel nervous. Last night in his

doppelgangers to the world. He had been building a secret army of sportsbots, one to represent each great competitor in history.

People laughed at first. The media didn't: they seized the moment, hailing the robots as the solution, at least until the honour of human sport could be reclaimed. They were desperate.

The robots were programmed with the skill levels of the sporting heroes on whom they had been modelled. The message was clear: no more cheating.

The media weren't the only ones pleased by this solution. Sports veterans (and their dwindling bank accounts) were glad to workshop, my master tampered with one of the synthetic strips on my surface and inserted a micro-device underneath.

"With this," he said, leaning close to me, "I can remotely manipulate your flightpath during the game."

"Isn't that cheating?" he then said, speaking on my behalf.

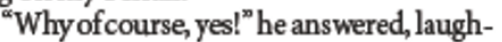
ing. "You won't tell anyone will you?"

No, I never tell.

Besides being an avid footy fan, Paul Steven Miller is a scientific researcher and obsessive sci-fi writer, seeking publication for his first novel The Humanoid Foundation. 